\title{
Drama and theatre in teaching foreign languages for professional purposes
}

Théâtre et enseignement des langues de spécialité Stefanie Giebert

p. $138-150$

\section{Résumés}

English Français

Cet article met en lumière le rôle du théâtre dans l'apprentissage des langues dans l'enseignement supérieur, notamment dans l'acquisition de compétences professionnelles. Dans une première partie, les formes théâtrales utilisées dans l'enseignement des langues seront brièvement décrites. Leurs avantages, tels que la contextualisation de la langue, une approche holistique de l'apprentissage, une meilleure mémorisation de la langue ou encore un enrichissement des compétences inter-personnelles des apprenants, seront étudiés. Dans la deuxième partie seront abordés les avantages du théâtre dans l'acquisition de compétences professionnelles. Un exemple concret d'enseignement par le théâtre sera présenté : des projets théâtraux ayant pour objectif de développer l'anglais commercial.

\section{Entrées d'index}

\section{Mots-clés :}

théâtre, enseignement supérieur, compétence professionnelle, anglais de spécialité (ASP)

\section{Keywords :}

drama, English for special purposes, tertiary/higher education, professional competence, holistic learning

Haut de page 


\section{Résumés}

English Français

The article discusses how drama can support language learning at the university level and how drama can also support learners in acquiring professional competences. In the first part, the article will briefly outline forms of drama in language teaching. It will discuss its benefits, such as putting language in context, making learning holistic and memorable, improving learners' social and personal competences. The second part describes aspects of drama beneficial for language learning in a professional context and gives a concrete teaching example: theatre projects with a focus on business English.

Haut de page

\section{Entrées d'index}

\section{Mots-clés :}

théâtre, enseignement supérieur, compétence professionnelle, anglais de spécialité (ASP)

\section{Keywords :}

drama, English for special purposes, tertiary/higher education, professional competence, holistic learning 


\section{Plan}

1. Introduction

2. Drama in foreign language teaching: how can it be described?

3. Benefits for language teaching

3.1. Contextualising language and providing a safe environment

3.2. Sustainable, holistic learning

3.3. Improving personal and social competences

3.4. Motivation

4. Drama and languages for special purposes/professional contexts

5. Teaching experience: business English theatre projects

6. Conclusion

Texte intégral 


\section{Introduction}

- 1 http://www.ucc.ie/en/scenario/researchbibliography/.

1The use of drama in the teaching of foreign languages is not a new approach-its beginnings can be traced back to the $19^{\text {th }}$ century (Schewe 2007). Since the late 1970s, with the increasing prevalence of the Communicative Approach, the method has been an integral part of foreign language teaching - for the area of English as a foreign language see for example Via's English in Three Acts (1976). The author draws on his teaching experiences in Japan with his theatre company Model Productions and the related Model Language Studios. Other exemplary books from this time are Holden's Drama in Language Teaching (1981) and Maley \& Duff's Drama Techniques in Language Learning (2009). A large and continuously updated online research bibliography attests to on-going scholarly interest in the topic1. However, most academic publications on drama in language teaching focus on its use in primary or secondary school and/or on general language learning. Not many publications look at using drama in the teaching of languages for special purposes to university level learners, which is to be the focus of this article.

2The article is divided into two parts: First, an overview of the field of drama in language teaching in general, with reference to selected publications, will be given with a summary of the arguments commonly listed in favour of using drama techniques in the foreign language classroom. Secondly, the topic of drama in teaching languages for special/vocational purposes will be looked at in more detail in combination with a report on a teaching experience, i.e. a full-scale theatre production with a focus on business English.

\section{Drama in foreign language teaching: how can it be described?}

3It is not the aim of this article to give an exhaustive description of which forms drama can take in the foreign language classroom (for a large collection of formats suitable for the foreign language classroom see for example Maley \& Duff 2009). However, a short definition of drama will be provided in connection with an overview of some criteria that can be used to classify the different formats of activities.

4A widely cited definition of drama comes from Holden (1981: 1) who defines it as "any activity which asks the student to portray a) himself in an imaginary situation or b) another person in an imaginary situation" - a definition which can be applied to most formats of drama in language teaching and includes role-play as a form of drama. However, vocal and physical exercises that do not imply the creation of a fictional character or situation, such as articulation exercises or movement games, should also be included. Therefore, for a description that is wider in scope, the following characteristics can be used to classify drama activities.

- Short/long: a drama game can be played in only a few minutes while a drama project can extend over several months or longer. 
- Non-verbal/verbal: while the use of verbal activities for language learning seems selfexplanatory, non-verbal exercises can also have their benefit, for example as icebreakers to decrease learners' anxiety or to provide topics for discussion or to broaden learners' perspective on a foreign language by drawing their attention to aspects of body language.

-

- 2 "Process Drama, a term widely used in North America (but originally from Australia) and synonymous (...)

- 3 For a detailed exploration of how different drama activities can be used for grammar teaching cf. E (...)

Open/closed: Kao \& O’Neill (1998: 5-18) suggest a continuum model of drama approaches ranging from "closed/controlled" (script-based) to "open communication" with process drama2 at the far end of the spectrum. Open forms will foster creative language use (focus on meaning) and while they can be used with lower-level learners, they may be more fruitful if a certain level of language competence has already been achieved. Closed forms (among which Kao \& O'Neill also include language games), on the other hand, are suitable for a focus on accuracy/focus on form - for pronunciation, vocabulary, and grammar or text-genre practice but they can also be used for the introduction of new linguistic input3. Again, different teaching aims and learner needs will necessitate different approaches.

$\bullet$

- 4 The latter two are so-called dramatic conventions, which are listed in many resource books, e.g. $\mathrm{Ne}(. .$.

- 5 It might look as if closed forms are automatically product-oriented while open ones are process-ori (...)

Process-oriented/product-oriented: Is there an audience-product-oriented approach-or is the focus on the experience of the participants-process-oriented approach (cf. Moody 2002 and Fleming 2006)? Product-oriented forms can be more motivating for learners who prefer working towards a concrete end-product (Fonio \& Genicot 2011; Schewe \& Scott 2003) and they tend to be more beneficial for a focus on accuracy. On the one hand, process-oriented approaches are argued to be more creative (Glock 1993; Kao \& O'Neill 1998) and liberating for certain learners (Culham 2002) as fluency is valued over accuracy and there is no (or less) pressure to perform flawlessly. On the other hand, process and product can be connected in drama projects, e.g. as students' process-oriented explorations of a topic (improvisations, hot-seating, thought-tracking, etc.4) are turned into a scripted play which is rehearsed and eventually publicly performed5.

\section{Benefits for language teaching}

$5 A$ number of articles outline the benefits of drama in language teaching. Overviews are, for instance, given by Sam (1990), Boudreault (2010) and Royka (2002). A limited number of empirical studies have aimed to prove its beneficial effects. The earliest studies date from the 1980s and 1990s. Stern (1983) examined psycholinguistic aspects, while Gaudart (1990) 
focused on different formats' effectiveness in different school types. In a more recent study, O'Gara (2008) examined the effectiveness of drama for teaching verb tenses in a secondary school setting, while Kao \& O'Neill (1998) tested the effectiveness of process drama for oral communication among adult learners of English as a second language. In addition, Gill (2013) names Miccoli (2003), Stinson (2007), Stinson \& Freebody (2006a; 2006b), and Ulas (2008) as "international studies which show the extent to which drama works". The benefits of drama in language teaching are summarised in the following sections.

\subsection{Contextualising language and providing a safe environment}

6Drama activities lend meaning to language structures by letting students experience the language in concrete situations. Learners are, for example, not simply given a list of phrases typical for meetings to memorise for a vocabulary test but have to role-play a meeting situation-and can thus memorize difficult phrases in context. Here, parallels to communicative language teaching are apparent but Fleming (2006) describes how drama can go further:

- 6 The term drama is here also used in the sense of Susan Holden's definition.

For example, instead of a simple scenario of buying an article in a shop, the teacher might set up a richer context in which the two participants knew each other at school and were great rivals. It is in this way that drama techniques can be used to explore thoughts and feelings"6.

7Learners can practise using language and behaviour adequate to potentially complex situations in the safety of the classroom. To extend Fleming's example, while in a real life situation using the wrong register might lead to a conflict between the client and the shopkeeper, in the classroom the situation can be analysed after being acted and/or frozen, slowed down or repeated with an alternative outcome. Moreover, the role of a fictional persona is often felt by learners to be a kind of protection and they seem to experience less embarrassment about making mistakes.

\subsection{Sustainable, holistic learning}

8In general, drama activities involve physical activity and emotional involvement which can lead to improved retention of language structures and vocabulary, as examined by O'Gara (2008), Kao \& O’Neill (1998) and Sambanis (2013).

9The physical aspect, which includes non-verbal (body-language, proxemics) and para-verbal communication (intonation and stress, volume, pauses) can become relevant to learning on several levels, as outlined by Gregersen (2007). On the phoneme level, pronunciation and articulation games can help learners to explore the sounds of the target language. On the word/phrase level, accompanying words and phrases with gestures can make them more memorable (Sambanis 2013; Schiffler 2012) and can help learners to internalise the correct rhythm and intonation (Dubrac 2013). Furthermore, movement can be used to illustrate grammatical aspects (Lapaire 2006). Integrating non-verbal activities can raise the confidence-level and motivation of shy and/or weaker learners. It can also encourage them 
to speak more because they will find that they can complement their verbal skills through non-verbal aspects (Culham 2002).

10Emotional aspects are involved in drama activities on both a direct and a meta-level. On the one hand, feelings are directly involved by acting them in role-playing. On the other hand, learners will have an emotional attitude towards the drama activities themselves. Ideally, positive feelings such as enjoying a collaborative and creative atmosphere and pride in achievement will prevail but even if negative emotions such as insecurity or stage-fright are occasionally experienced, the learning will be more memorable than in a neutral, predominantly cognitive setting, as it is set apart from other events. According to DeCoursey: "Damasio [1994] suggests that when there is an emotional response to a perception or a bit of learning, the brain marks it as useful to the organism. So why do drama in the language classroom? In order to mark elements of language with emotion so that students will remember them" (2012: 7).

\subsection{Improving personal and social competences}

11Drama activities can increase students' self-confidence (cf. e.g. Stern 1983; Schewe \& Scott 2003) and decrease fear of using the foreign language spontaneously. Since drama activities are largely collaborative, learners can also improve their social competences. Moreover, exploring identities beyond their own through inhabiting fictional characters can support learners in developing their capability for empathy.

\subsection{Motivation}

12As a result of the above-mentioned aspects, language learning motivation may be increased because of more (physically) active learning including the learner's whole person, an experience of collaboration, a sense of achievement and taking joy in a creative approach.

\section{Drama and languages for special purposes/professional contexts}

13 Having looked at drama in foreign language teaching in general, it can be said that most of the benefits listed above apply also to the teaching of languages for professional/special purposes. This article suggests that drama can be helpful for an ESP (English for Special Purposes) classroom in a number of ways.

14Drama can provide context for the learning of specialised vocabulary and for learners to actively practise work-related (oral) activities and genres, such as meetings, making appointments, business dinners, etc. As Brennan \& Pearce (2009), DiNapoli $(2001 ; 2009)$ and Pearce \& Jackson (2009) outline in their articles about the dramatization of case studies or of particular concepts from the business world (such as the life-cycle of products), topics and material which might appear 'dry' to students at first glance can be made more accessible and memorable as students start to identify with characters in case studies and experience emotional involvement through dramatic tension. 
15Dramatic play simulating business life can show students the importance of emotions in professional contexts. Marketing and design are fields where customers' emotions have long been recognised as influential factors, but research in behavioural economics shows that the field of finance is not as rational as previously assumed by theorists. Even students from science and engineering, who possibly tend to take a predominantly rational view on life, might profit from being aware of the 'soft' factors in communication as they can be explored through drama.

16Drama activities encourage learners to explore topics of identity, as students can literally experience 'walking in somebody else's shoes' when they take on fictional identities. This can be beneficial for exploring professional roles, both linguistically (register, jargon) as well as on a more personal level, and help young graduates to negotiate their own eventual future professional identity.

- 7 http://rationalmadness.wordpress.com/treasures/plays-and-scripts/.

17According to Garaventa (1998), alternative perspectives on business topics (such as moral values in business, leadership, etc.) can be explored through reading and acting out dramatic literature such as Arthur Miller's Death of a Salesman to explore business ethics. Augustine \& Adelmann (1999) examine connections between Shakespeare plays and leadership topics, such as confronting change or crisis management. Similarly, DiNapoli (2001) suggests early $20^{\text {th }}$ century plays such as Waiting for Lefty and Death of a Salesman as examples for study, but Internet sources also offer more contemporary plays, specifically written to explore work-related issues such as Recycled Dreams and Bunk7.

- 8 Thought-tracking is a dramatic convention where a scene is frozen and the actors voice the thoughts (...)

18Drama activities have potential for teaching intercultural competence in a holistic way: For example when intercultural encounters are role-played in combination with thoughttracking 8 and these scenes are then discussed. In such an exercise students will see the behaviour of the persons acting in the scene (exterior perspective). They will also see what the actors are thinking (interior perspective). They will become aware that behaviour they perceive as offensive may have been shaped by different cultural standards and may not have been offensive at all to someone from a different culture. To illustrate this: A student playing a Chinese guest at a business dinner scene slurps when eating. The student playing the European host shows irritation. The thought-tracking reveals that the Chinese guest was trying to be especially appreciative of the food and is now confused that his host is apparently angry at him. The host, on the other hand, reveals in his thoughts that he tried to please his guest with special food and is now hurt that the guest doesn't seem to appreciate it. Nowadays employers expect their staff to be "skilful negotiators in increasingly intercultural work situations" (Sercu et al. 2005: 1), thus language teachers have to pay more and more attention to the (often non-verbally mediated and emotionally charged) differences in communication styles between people of different cultural backgrounds. Roleplaying exercises such as the one described above combined with a group discussion can provide helpful tools for exploring this topic (cf. Byram \& Fleming 1998). 


\section{Teaching experience: business English theatre projects}

19For a concrete example, a teaching experience with a product-oriented, long-term drama format shall be described in this section. In this example, students at a university of applied sciences take part in a full-scale theatre production for a whole semester. In this voluntary course they can act in plays specifically written for this group and usually centring on topics from the world of business and industry-such as the finance sector in an adaptation of Shakespeare's Merchant of Venice or the globalised textile industry in an evening of short plays about fashion, where learners encounter business-related situations in the script, such as making appointments, being in a job interview or receiving business partners from abroad. In some semesters, students help to develop the script themselves by improvising scenarios, which are then filmed, transcribed and edited into a dramatic script; in other semesters (depending on the amount of time available) the script is written entirely by the director/teacher.

20The topic of globalisation, and more concretely, globalisation of the textile industry and the production- and distribution-chain of jeans was the focus of a semester-project in 2012. Within approximately ten weeks, an evening of short plays was developed, rehearsed and presented in a show on campus by a group of ten students. In the first three meetings, students were given background reading, brainstormed ideas for plays about jeans, made mind-maps and eventually the director/teacher wrote drafts for seven short plays (five to fifteen minutes) to be further developed in the rehearsal process. Three to four rehearsals a week were held, students rehearsed in small groups. Topics ranged from selling 'fast fashion' and sustainability to historical aspects (blue jeans in the American West in the 19th century) to a dystopic piece centring on the word-play jeans/genes and the topic of genetic engineering. Students encountered a range of specialised vocabulary from the fields of business and textile production (vocabulary). Furthermore they worked with a range of different genres from Western over fairy tale to Shakespeare-inspired monologue (cultural learning). They practised articulation and pronunciation (oral expression, presentation skills), especially in one rather abstract piece which included choral speaking and relied very much on expressive delivery of the lines for the play to be effective, that is, interesting for an audience. As students from Belgium, Vietnam, Russia, Malaysia and Germany were involved in the project and partly struggled with pronunciation and intonation issues, an American native speaker worked with them in some rehearsals as a pronunciation coach.

21Apart from being actors, the students can also work as costume designers, marketing managers and organisers, as a full-scale theatre-production involves the cooperation of different specialist groups (actors, production managers for stage, costumes, lights and sound, marketing team, etc.). This not only gives them the opportunity to develop social competences through teamwork but also provides room for students with different talents to contribute to the overall outcome, which can help to motivate heterogeneous learner groups and/or can provide occasions for inter-faculty cooperation. In the given example, students from textile technology, business studies and the school of technology cooperate and thus interdisciplinary teamwork can be practised. In evaluations of the theatre project, 
working as part of a mixed group has been frequently mentioned as a positive experience by participants. In research articles about interdisciplinary student theatre projects conflicts within groups are occasionally reported, but both positive and negative aspects of teamwork contribute to students' professional development, as this mixture mirrors workplace processes as well (Carson 2012: 56).

22Apart from practising their spoken English (the working language throughout the whole project is naturally English), students can also practise basic (work-related) writing skills since part of the scheduling is done via e-mail and students are required to communicate with the director in English. In addition, students are encouraged to contribute texts for marketing and for the programme brochure and thus have the opportunity to practise a variety of written text genres.

- 9 Drama-projects at other universities provide students also with authentic contact to native speaker (...)

23This project format is also useful to train learners' time- and project-management skills, since public performances require a considerable amount of planning and organising skills. However, the idea of a concrete end-product (the performance) also increases participants' motivation9 and sense of responsibility for the outcome. As Fonio \& Genicot observe:

In language drama class, the learners' motivation to interact stems from the fact that they have to accomplish the tasks in a very specific way, because other more complex tasks-and the final performance itself-depend on their accomplishment" (2011: 79).

24Another aspect of increasing responsibility for the outcome is having the students give feedback to other participants throughout the rehearsal process. Students will thus learn to take responsibility not only for their own individual learning process but also for that of the whole group. Since the group is usually mixed in regard to the students' acting experience, students who have acting experience can model successful behaviour and strategies (for example: the memorisation of lines, the control of voice and volume, etc.) for the less experienced and peer-learning is thus encouraged.

\section{Conclusion}

25As this article has outlined, language learners may accept drama as a means to acquire linguistic and non-linguistic competences for their future professional field. It can be used to teach grammar, pronunciation, vocabulary, intercultural aspects, and so-called soft skills such as presentation competence, teamwork skills and self-management. It can create memorable and practice-oriented learning experiences that improve learners' languagecompetence, employability and personal development. Therefore, it should not be regarded as merely a 'fun activity' that can be used to fill the last five minutes of class, when the 'real' learning already has been done but as a teaching approach in itself.

26However, for language learners to encounter drama at school or in university, their teachers need to be familiar and comfortable with it. Not all teachers feel at ease with employing drama in the classroom - there are constraints of time and space and not every 
teacher feels confident to use a method they have not been trained in (Royka 2002, Gaudart 1990).

27Therefore, the question arises of which role drama could play in teacher education. Is it sufficient to assume that teachers will simply learn by doing or is there a need for dramafocussed classes for teachers? The aim of this article was to draw attention to the benefits of drama in language teaching at universities but it will be in the hands of the institutions which train language teachers to establish drama as an accepted teaching method for foreign languages or to leave it in the relatively marginal position it occupies these days. 


\section{Bibliographie}

Augustine, N.R. \& K. Adelman, 1999. Shakespeare in Charge: the Bard's Guide to Leading and Succeeding on the Business Stage. New York: Hyperion-Talk-Miramax.

Boudreault, C. 2010. "The benefits of using drama in the ESL/EFL Classroom". The Internet TESL Journal, 16(1). http://iteslj.org/Articles/Boudreault-Drama.html (retrieved 31 October 2013).

Brennan, R. \& G. Pearce. 2009. "Educational drama: a tool for promoting marketing learning?" International Journal of Management Education, 8(1): 1-10.

Byram, M. \& M. Fleming. 1998. Language Learning in Intercultural Perspective: Approaches through Drama and Ethnography. Cambridge: Cambridge University Press.

Carson, L. 2012. "The role of drama in task-based learning: Agency, identity and autonomy". Scenario, 6(2): 47-60. http://research.ucc.ie/scenario/2012/02/Carson/06/en (retrieved 25 July 2013).

Carolan, S., C. Evain \& C. Bertail. 2012. "The word for word project: A stage of opportunity". Presentation at the conference "Languages in Motion", Université de Nantes, 6 September 2012.

Culham, C. 2002. "Coping with obstacles in drama-based ESL teaching: A nonverbal approach". In Bräuer, G. (Ed.). Body and Language. Westport, CT: Ablex Publishing, 95-112.

Damasio, A. 1994. Descartes' Error-Emotion, Reason and the Human Brain. New York: G. P. Putnam's Sons.

DeCoursey, M. 2012. "Dramatic art for second language education: Appropriate process objectives for Hong Kong schools". Asia-Pacific Journal for Arts Education, 11(11): 250-270. http://www.ied.edu.hk/cca/apjae/Vol11_No11.pdf (last accessed 25 July 2013).

DiNapoli, R. 2001. "The power of dramatizing case studies in ESP". The Journal of the Imagination in Language Learning and Teaching, VI.

http://www.njcu.edu/cill/vol6/index.html (retrieved 25 July 2013).

DiNapoli, R. 2009. "Using dramatic role-play to develop Emotional aptitude". International Journal of English Studies, 9(2). http://revistas.um.es/ijes/article/view/90771/87571 ( retrieved 25 July 2013).

Dubrac, A.L. 2013. "Using theatre techniques in the language classroom". Conference presentation at the $8^{\text {th }}$ Drama and Education IDEA World Conference, Paris, 8 July 2013.

Even, S. 2003. Drama Grammatik : Dramapädagogische Ansätze für den Grammatikunterricht Deutsch als Fremdsprache. München: ludicium. 
Fleming, M. 2006. “Drama and language teaching: the relevance of Wittgenstein's concept of language games". Humanising Language Teaching, 8(4): 97-110.

http://www.hltmag.co.uk/jul06/mart01.htm (retrieved 31 October 2013).

Fonio, F. \& G. Genicot. 2011. "The compatibility of drama language teaching and CEFR objectives-observations on a rationale for an artistic approach to foreign language teaching at an academic level". Scenario, 5(2): 75-89.

http://research.ucc.ie/scenario/2011/02/FonioGenicot/06/en (retrieved 31 October 2013).

Fonio, F. 2012. "Stuffed pants! Staging full-scale comic plays with students of Italian as a foreign language". Scenario, 6(2): 18-27.

http://research.ucc.ie/scenario/2012/02/Fonio/04/en (retrieved 25 July 2013).

Gaudart, H. 1990. "Using drama techniques in language teaching”. In Sarinee, A. (Ed.). Language Teaching Methodology for the Nineties. Anthology Series 24. Singapore: Regional Language Centre, 230-249.

Garaventa, E. 1998. "Drama-a tool for teaching business ethics". Business Ethics Quarterly, 8(3): 535-545.

Gill, C. 2013. "Enhancing the English-language oral skills of international students through drama". English Language Teaching, 6(4): 29-41.

Glock, C. 1993. "Creating language contexts through experiential drama”. In Schewe, M. \& P. Shaw (Eds.). Towards Drama as a Method in the Foreign Language Classroom.

Frankfurt/M.: Lang, 103-138.

Gregersen, T. 2007. "Language learning beyond words: Incorporating body language into classroom activities". Reflections on English Language Teaching, 6(1): 51-64.

Holden, S. 1981. Drama in Language Teaching. Harlow: Longman.

Kao, S. \& C. O’Neill. 1998. Words into Worlds. Stamford, CT: Ablex Publishing.

Lapaire, J.-R. 2006. La grammaire anglaise en mouvement. Paris: Éditions Hachette.

Liu, J. 2002. "Process drama in second- and foreign-language classrooms". In Bräuer, G. (Ed.). Body and Language. Westport, CT: Ablex Publishing, 52-70.

Maley, A. \& A. Duff. 2009 [1978]. Drama Techniques, $3^{\text {rd }}$ ed., $4^{\text {th }}$ print. Cambridge: Cambridge University Press.

Miccoli, L. 2003. "English through drama for oral skills development". ELT Journal, 57(2): 122-129.

Moody D.J. 2002. "Undergoing a process and achieving a product: A contradiction in educational drama?". In Bräuer, G. (Ed.). Body and Language. Westport, CT: Ablex Publishing, 135-160. 
Neelands, J. \& T. Goode. 2000. Structuring Drama Work: A Handbook of Available Forms in Theatre and Drama. Cambridge: Cambridge University Press.

O'Gara, P. 2008. "To be or have not been: Learning language tenses through drama". Issues in Educational Research, 18(2): 156-166.

Pearce, G. \& J. Jackson. 2009. "Experiencing the product life cycle management-highs and lows through dramatic Simulation". Journal of Marketing Education, 31(3): 212-218.

Royka, J. (2002). "Overcoming the fear of using drama in English language teaching". The Internet TESL Journal, 8(2). http://iteslj.org/Articles/Royka-Drama.html (retrieved 25 July 2013).

Sam, W.Y. 1990. "Drama in teaching English as a second language-a communicative approach". The English Teacher, 19(7). www.melta.org.my/ET/1990/main8.html (retrieved 28 November 2013).

Sambanis, M. 2013. Fremdsprachenunterricht und Neurowissenschaften. Tübingen: Narr.

Schewe, M. \& T. Scott. 2003. "Literatur verstehen und inszenieren-foreign language literature through drama. A research project". GFL - German as a Foreign Language. 2003 (3): 56-83. http://www.gfl-journal.de/3-2003/schewe_scott.pdf (retrieved 25 July 2013).

Schewe, M. 2007. "Drama und Theater in der Fremd- und Zweitsprachenlehre: Blick zurück nach vorn“. Scenario, 1(1): 154-169. publish.ucc.ie/scenario/2007/01/schewe/08/de (retrieved 31 October 2013).

Schiffler, L. 2012. Effektiver: Bewegung - Visualisierung - Entspannung. Tübingen: Narr.

Sercu, Lies et al. (Eds.) 2005. Foreign Language Teachers and Intercultural Competence. Cleveland: Multilingual Matters.

Stern, S.L.1983. "Why drama works: A psycholinguistic perspective". In Oller, J. \& P. RichardAmato (Eds.). Methods that work. Rowley: Newberry House Publishers, 207-225.

Stinson, M. 2007. "Speaking out: An exploration of process drama and its contribution to oracy". Final Research Report for Project No. CRP 27/04 MS. Centre for Research in Pedagogy and Practice.

Stinson, M. \& K. Freebody. 2006a. "The DOL Project: An investigation into the contribution of process drama to improved results in English oral communication". Youth Theatre Journal, 20: $27-41$.

Stinson, M. \& K. Freebody. 2006b. "Modulating the mosaic: Drama and oral language". In McCammon, L., A. \& D. McLauchlan (Eds.). Universal Mosaic of Drama and Theatre: The IDEA04 Dialogues. Ottawa: IDEA Publications, 193-201. 
Ulas, A.H. 2008. "Effects of creative, educational drama activities on developing oral skills in primary school children". American Journal of Applied Sciences, 5(7): 876-880.

Via, R.A. 1976. English in Three Acts. Hawaii University Press. 


\section{Notes}

1 http://www.ucc.ie/en/scenario/researchbibliography/.

2 "Process Drama, a term widely used in North America (but originally from Australia) and synonymous to 'educational drama' or 'drama in education' in Britain, is concerned with the development of a dramatic world created by both the teacher and the students working together." (Liu 2002: 55).

3 For a detailed exploration of how different drama activities can be used for grammar teaching cf. Even 2003.

4 The latter two are so-called dramatic conventions, which are listed in many resource books, e.g. Neelands \& Goode 2000.

5 It might look as if closed forms are automatically product-oriented while open ones are process-oriented but this is not necessarily the case. Although the connection is often there, other combinations are possible: on the one hand, students might work with scripts without intending to perform, a script might be developed from improvisations or students might improvise on a given script. On the other hand, open improvisation can be done in front of or even actively involving an audience (e.g. theatre sports).

6 The term drama is here also used in the sense of Susan Holden's definition.

7 http://rationalmadness.wordpress.com/treasures/plays-and-scripts/.

8 Thought-tracking is a dramatic convention where a scene is frozen and the actors voice the thoughts their characters have at that moment.

9 Drama-projects at other universities provide students also with authentic contact to native speakers, as e.g. when a production is taken to a festival in an L2 country, which requires learners to organise travel (Fonio 2012) or a theatre-company of native speakers is hosted by the university and the students turn into stage-designers and event-managers for a professional performance (Carolan et al. 2012). This factor tends to increase motivation further, as it did in the given example when exchange students from English-speaking countries participated in the project and non-native participants stressed that they enjoyed interacting with the native-speakers. 


\section{Pour citer cet article}

\section{Référence papier}

Stefanie Giebert, " Drama and theatre in teaching foreign languages for professional purposes ", Recherche et pratiques pédagogiques en langues de spécialité, Vol. XXXIII N 1 | 2014, 138-150.

\section{Référence électronique}

Stefanie Giebert, «Drama and theatre in teaching foreign languages for professional purposes ", Recherche et pratiques pédagogiques en langues de spécialité [En ligne], Vol. XXXIII N ${ }^{\circ} 1$ | 2014, mis en ligne le 10 mars 2014, consulté le 03 novembre 2015. URL : http://apliut.revues.org/4215 ; DOI : 10.4000/apliut.4215

\section{Auteur}

Stefanie Giebert

Stefanie Giebert holds a PhD in English from Trier University, Germany. She works at Reutlingen University of Applied Sciences in Germany and moreover as a freelance trainer for English, presentation skills, intercultural communication and theatre. Her research interest is teaching English as a foreign language through drama.

Stefanie.Giebert@Reutlingen-University.DE

Droits d'auteur

Association des Professeurs de Langues des Instituts Universitaires de Technologie 